\title{
NORTHERN PEATLANDS: ROLE IN THE CARBON CYCLE AND PROBABLE RESPONSES TO CLIMATIC WARMING ${ }^{1}$
}

\author{
EVILLE GoRHAM \\ Department of Ecology, Evolution and Behavior \\ University of Minnesota, Minneapolis, Minnesota 55455 USA
}

\begin{abstract}
Boreal and subarctic peatlands comprise a carbon pool of $455 \mathrm{Pg}$ that has accumulated during the postglacial period at an average net rate of $0.096 \mathrm{Pg} / \mathrm{yr}(1 \mathrm{Pg}=$ $10^{15} \mathrm{~g}$ ). Using Clymo's (1984) model, the current rate is estimated at $0.076 \mathrm{Pg} / \mathrm{yr}$. Longterm drainage of these peatlands is estimated to be causing the oxidation to $\mathrm{CO}_{2}$ of a little more than $0.0085 \mathrm{Pg} / \mathrm{yr}$, with combustion of fuel peat adding $\approx 0.026 \mathrm{Pg} / \mathrm{yr}$. Emissions of $\mathrm{CH}_{4}$ are estimated to release $\approx 0.046 \mathrm{Pg}$ of carbon annually.

Uncertainties beset estimates of both stocks and fluxes, particularly with regard to Soviet peatlands. The influence of water table alterations upon fluxes of both $\mathrm{CO}_{2}$ and $\mathrm{CH}_{4}$ is in great need of investigation over a wide range of peatland environments, especially in regions where permafrost melting, thermokarst erosion, and the development of thaw lakes are likely results of climatic warming. The role of fire in the carbon cycle of peatlands also deserves increased attention. Finally, satellite-monitoring of the abundance of open water in the peatlands of the West Siberian Plain and the Hudson/James Bay Lowland is suggested as a likely method of detecting early effects of climatic warming upon boreal and subarctic peatlands.
\end{abstract}

Key words: biomass; carbon cycle; carbon dioxide; climate warming; greenhouse effect; methane; mires; peatlands.

\section{INTRODUCTION}

Peatlands are characteristic of waterlogged situations in which, owing to anoxic and cool conditions a few centimetres or decimetres beneath the surface, organic detritus accumulates, usually on relatively flat landscapes, to depths $>30$ or $40 \mathrm{~cm}$ (depending upon which country's definition is accepted) and often up to several metres. Peat may consist predominantly of reed, cattail, and sedge remains where water enriched in bases and nutrients from surrounding mineral soils percolates through the surface peat; such peatlands are termed minerotrophic fens. Where peatlands in wet climates are domed above the surrounding landscape and inputs of bases and nutrients to the peat surface are derived solely from the atmosphere, the peat consists primarily of the remains of Sphagnum mosses; these peatlands are termed ombrotrophic bogs. Many flat peatlands also have an abundance of Sphagnum (Kulczynski 1949; W. D. Billings, personal communication). Situations such as these are prevalent over large areas in the boreal and subarctic zones (Gore 1983), in which are locked up vast amounts of carbon sequestered from the atmosphere by photosynthesis and not yet released by decomposition.

Human activities, primarily drainage, have affected the carbon balance of peatlands substantially (Armentano and Menges 1986, Gorham 1988). Changing climatic conditions can also be expected to affect greatly

\footnotetext{
${ }^{1}$ Manuscript received 19 March 1990; accepted 1 June 1990; final version received 6 August 1990.
}

the balance between photosynthesis and decomposition in peatlands, with "greenhouse" warming of the climate, especially at high latitudes (Post 1990), the most likely cause of change.

Peatlands are unusual in "greenhouse" scenarios because on the one hand they sequester the major "greenhouse" gas, $\mathrm{CO}_{2}$, from the atmosphere as peat, while on the other hand they emit to it in large quantities both $\mathrm{CO}_{2}$ and the second most important "greenhouse" gas, $\mathrm{CH}_{4}$ (Moore and Knowles 1987, 1989). Research on these ecosystems should focus, therefore, on the effects of climatic warming upon two aspects of peatland ecology and biogeochemistry: (1) the balance between $\mathrm{CO}_{2}$ fixation and release, and (2) the balance between $\mathrm{CH}_{4}$ production and consumption.

The influence of climatic warming upon the carbon cycle in peatlands will be largely indirect. Although rates of photosynthesis, decomposition, and $\mathrm{CH}_{4}$ emission may all be expected to increase directly with rising temperatures and longer growing seasons, such effects are likely to be strongly overshadowed by those caused indirectly by hydrological changes, especially alterations in the level of the water table (Moore and Knowles 1989), induced by climatic warming. These effects will probably include substantial water table drawdowns and peat oxidation, in southerly regions owing to greater evapotranspiration, and in more northerly locations, where precipitation may increase appreciably (Grotch 1988), to melting of the permafrost. Such melting will probably cause a good deal of thermokarst erosion (Billings et al. 1982) that will lower water tables in 
many areas. However, it will also cause the formation of many shallow thaw ponds and lakes. These will probably release a good deal of $\mathrm{CO}_{2}$ by oxidation of eroded peat particulates, but the initiation of hydrosere succession in many of them will lead eventually to renewed peat accumulation (Chapin et al. 1980, Luken and Billings 1983).

Climatic warming may renew peat accumulation in subarctic peatlands (Gorham 1988, 1990), where it ceased long ago owing to climatic cooling and the development of continuous permafrost (Zoltai and Tarnocai 1975, Zoltai and Pollett 1983). It may also shift peatland formation, like the tree line (Miller 1981), into landscapes even farther north. Therefore, the topography of those landscapes will govern where entirely new peat deposits will accumulate. The importance of the topographic factor is evident in the location of the two major peatland areas in the world. The largest lies on the vast and nearly level West Siberian Plain between the $\mathrm{Ob}$ and Yenisey rivers in the USSR (Neishtadt 1977, Walter 1977, Neustadt 1984). Slopes may vary from $0.1-0.8$ in 1000 in wet "aapa" peatlands to as much as 4 in 1000 in less wet sites. The peats are also underlain by relatively impermeable substrates (Walter 1977). The next largest peatland occupies the Hudson/James Bay Lowland of Canada, another region of flat topography where the slope is commonly less than 1 in 1000, and where relatively impermeable marine silt/clays and other deposits favor waterlogging (Riley 1982).

In this review, because more and better information is available concerning carbon stocks, rates of accumulation, and $\mathrm{CH}_{4}$ emissions in North American peatlands, attention will be focused upon them. Attempts will be made, however, to use available Eurasian data and to produce global estimates.

\section{Current Carbon Stocks and Distribution}

There is far more carbon in the peat beneath the surface than in the vegetation currently growing on that surface. Boreal and subarctic regions contain the largest areas of peatland, although some is found in more temperate and even tropical parts of the world (Gore 1983).

\section{Total carbon pool in boreal and subarctic peat}

Boreal and subarctic peatlands are located almost wholly in the USSR, Canada, the USA and the Fennoscandian countries, with a total area of $346 \times 10^{6}$ ha. Of that area $\approx 11.5 \times 10^{6}$ ha, or $3.3 \%$, has been drained (Table 1), and about $4.4 \times 10^{6}$ ha $(1.3 \%)$ has been mined for horticultural peat and fuel (Kivinen and Pakarinen 1981).

The mean depth of boreal and subarctic peatlands is estimated to be $2.3 \mathrm{~m}$ (Table 1). Using a mean bulk density of $112 \mathrm{~g} / \mathrm{L}$ and a carbon content of $51.7 \%$ of dry mass (much higher than the $40 \%$ in carbohydrates),
TABLE 1. Areas and depths of boreal and subarctic peatlands.

\begin{tabular}{lccc}
\hline \hline & \multicolumn{2}{c}{ Area $\left(10^{6} \mathrm{ha}\right)$} & $\begin{array}{c}\text { Mean depth } \\
(\mathrm{m})\end{array}$ \\
\cline { 2 - 4 } & Total & Drained & $2.5 \|$ \\
USSR & $150^{*}$ & $3.9^{*}$ & $2.2 \Uparrow$ \\
Canada & $119 \dagger$ & $0.1^{*}$ & $2.5 \#$ \\
USA & $55 \ddagger$ & $0.6 \S$ & $1.1^{* *}$ \\
Fennoscandia & $22^{*}$ & $6.9^{*}$ & $2.3 \dagger \dagger$ \\
Total & 346 & 11.5 & \\
\hline
\end{tabular}

* Data from Kivinen and Pakarinen (1981).

$\dagger$ Modified from Tarnocai (1984); see Major uncertainties, Carbon stock, but with new data for Ontario (Riley 1988).

$\ddagger$ Alaska (Kivinen and Pakarinen 1981); Minnesota, Michigan, Wisconsin, Maine, New Hampshire, Vermont, and Washington (McKinzie 1982).

$\S$ Calculated by applying percent drainage in Minnesota to all of the states in the previous footnote except Alaska.

|l Estimate based on Neustadt (1984).

II Data compiled by E. Gorham, J. A. Janssens, S. C. Zoltai, and R. S. Clymo (unpublished manuscript).

\# Estimated by comparison with Canadian data.

** Data from Lappaleinen (1980).

$\dagger$ Weighted for area.

both derived from extensive Canadian data sets (Gorham 1988, 1990), we can then estimate readily the total carbon in the dry mass of boreal and subarctic peat, subtracting the mined area, as $\left(3.42 \times 10^{12} \mathrm{~m}^{2}\right) \times(2.3$ $\mathrm{m}) \times\left(112 \times 10^{3} \mathrm{~g} / \mathrm{m}^{3}\right) \times(0.517)=455 \times 10^{15} \mathrm{~g}$, or 455 petagrams $(\mathrm{Pg})$. This amounts to about one-third of the total world pool of soil carbon $(1395 \mathrm{Pg})$ estimated by Post et al. (1982), and is substantially greater than their estimate of carbon tied up in moist and wet boreal forest and tundra (374 Pg, or $347 \mathrm{Pg}$ in Post et al. 1985).

The estimate of $455 \mathrm{Pg}$ given above is considerably higher than others, for instance my own earlier value (Gorham 1990) of $180-227 \mathrm{Pg}$, and that of $300 \mathrm{Pg}$ for global peatlands by Sjörs (1980). It is also higher than the estimate of $249 \mathrm{Pg}$ given by Armentano and Menges (1986) for northern peatlands, but they assumed an average depth of only $1 \mathrm{~m}$. If a depth of $2.3 \mathrm{~m}$ were used instead, their estimate would rise to $573 \mathrm{Pg}$. Oechel (1989) estimates boreal peatlands to contain only $210 \mathrm{Pg}$. A carbon pool of $455 \mathrm{Pg}$ for boreal and subarctic peatlands is very substantially greater than the global pools of dead organic matter estimated by Oechel (1989) for Arctic tundra, $55 \mathrm{Pg}$, and upland boreal forest, $88 \mathrm{Pg}$. These numbers would rise to 61 and 159 $\mathrm{Pg}$, respectively, if live biomass were added.

\section{Carbon pool in vegetation}

Total biomass of above- plus belowground vegetation in peatlands is extremely variable, depending on whether they are forested. Dry biomass in relatively open peatlands can be as low as $760 \mathrm{~g} / \mathrm{m}^{2}$, whereas in densely forested peatlands it can be almost 20 times as high, at $13800 \mathrm{~g} / \mathrm{m}^{2}$ (Grigal et al. 1985). Assuming a carbon content of $45 \%$ (Olson et al. 1983), these carbon mass values become 342 and $6210 \mathrm{~g} / \mathrm{m}^{2}$. The median dry biomass in 14 peatlands for which data 
were compiled by Bradbury and Grace (1983) and Grigal et al. (1985) is $2760 \mathrm{~g} / \mathrm{m}^{2}$ (carbon $1240 \mathrm{~g} / \mathrm{m}^{2}$ ), whereas the mean is $4430 \mathrm{~g} / \mathrm{m}^{2}$ (carbon $1990 \mathrm{~g} / \mathrm{m}^{2}$ ). The last of these carbon numbers is close to the estimate by Olson et al. (1983) of $2000 \mathrm{~g} / \mathrm{m}^{2}$, whereas Oechel (1989) estimates $2700 \mathrm{~g} / \mathrm{m}^{2}$.

\section{Vegetation vs. peat}

On a peatland area basis the global carbon pool of $455 \mathrm{Pg}$ (estimated above) amounts to $133000 \mathrm{~g} / \mathrm{m}^{2}$, as compared to $\approx 2000 \mathrm{~g} / \mathrm{m}^{2}$ tied up in vegetation. It appears, therefore, that $\approx 98.5 \%$ of total peatland carbon occurs in the form of peat, as against $\approx 1.5 \%$ in the vegetation.

\section{Carbon fluxes in boreal and subarctic peatlands}

Net carbon flux from the atmosphere to undrained peatlands can be estimated by adding to the data provided above a figure for the annual rate of increase in height. Unfortunately, owing to the slowness with which peatlands plants decompose, current rates of peat accumulation cannot be measured directly. Some evidence (Clymo 1984) suggests that decay may indeed continue anaerobically over hundreds and even thousands of years. Long-term rates can, however, be measured over thousands of years by radiocarbon dating.

Several such estimates for varying lengths of time in the postglacial are given in Table 2; those of E. Gorham, J. A. Janssens, S. C. Zoltai, and R. S. Clymo (unpublished manuscript) are derived wholly from 138 basal ${ }^{14} \mathrm{C}$ dates for the entire region. An overall height accumulation rate of $0.5 \mathrm{~mm} / \mathrm{yr}$ seems both conservative and reasonable. Assuming that this figure applies today, the dry-mass carbon flux from the atmosphere to undrained and unmined boreal and subarctic peatlands can be calculated as $\left(3.30 \times 10^{12} \mathrm{~m}^{2}\right) \times$ $\left(0.0005 \mathrm{~m} \mathrm{yr}^{-1}\right) \times\left(112 \times 10^{3} \mathrm{~g} / \mathrm{m}^{3}\right) \times(0.517)=0.096$ $\times 10^{15} \mathrm{~g} / \mathrm{yr}$, or $0.096 \mathrm{Pg} / \mathrm{yr}$. On an area basis this amounts to $29 \mathrm{~g} \cdot \mathrm{m}^{-2} \cdot \mathrm{yr}^{-1}$. Divided into the total pool of $439 \mathrm{Pg}$ for these same peatlands, a rate of $0.096 \mathrm{Pg} /$ yr yields an average age for the peat deposits of 4600 yr.

This estimate of long-term carbon storage at 0.096 $\mathrm{Pg} / \mathrm{yr}$ is very similar to my earlier estimate of 0.091 $\mathrm{Pg} / \mathrm{yr}$ (Gorham 1990) and also to that of Sjörs (1980), $0.090 \mathrm{Pg} / \mathrm{yr}$, for global peatlands. Silvola (1986) suggested a higher value, $0.110 \mathrm{Pg} / \mathrm{yr}$, for global peatlands, and Armentano and Menges (1986) a lower range, $0.050-0.075 \mathrm{Pg} / \mathrm{yr}$, for northern peatlands.

The assumption that the estimated overall accretion rate of $0.5 \mathrm{~mm} / \mathrm{yr}$ applies today is, however, unlikely as a general rule. Clymo (1984) has developed a model of decreasing peat accumulation over time, as follows: $m=p / \alpha)\left(1-e^{-\alpha t}\right)$, where $m=$ accumulated mass on an area basis at time $t, p=$ the annual rate of dry mass addition to the anaerobic peat mass, the catotelm, after
TABLE 2. Long-term height accumulation rates in boreal and subarctic peatlands, calculated as current peat depth $\div$ basal age.

\begin{tabular}{lc}
\hline \hline \multicolumn{1}{c}{ Location } & $\begin{array}{c}\text { Height } \\
\text { accumu- } \\
\text { lation rate } \\
\text { (mm/yr) }\end{array}$ \\
\hline $\begin{array}{l}\text { South Sweden and North Germany (median } \\
\text { value from Tolonen 1979) }\end{array}$ & 0.70 \\
$\begin{array}{l}\text { South and central Finland (median value from } \\
\text { Tolonen 1979) }\end{array}$ & 0.75 \\
$\begin{array}{l}\text { Northern Europe (Aaby 1986) } \\
\text { Boreal USSR (Botch and Masing 1983) }\end{array}$ & 0.60 \\
$\begin{array}{l}\text { Siberian palsa province (Botch and Masing } \\
\text { 1983) }\end{array}$ & $0.6-0.8$ \\
$\begin{array}{l}\text { Eurasia (Zurek 1976) } \\
\text { Subarctic Canada (E. Gorham et al., unpub- } \\
\quad \text { lished manuscript) }\end{array}$ & $0.2-0.4$ \\
$\begin{array}{l}\text { Boreal Canada (E. Gorham et al., unpublished } \\
\text { manuscript) }\end{array}$ & 0.52 \\
$\begin{array}{l}\text { Canada overall (E. Gorham et al., unpublished } \\
\text { manuscript) }\end{array}$ & 0.31 \\
\hline
\end{tabular}

aerobic decay has occurred in the acrotelm above, and $\alpha=$ the fraction of decomposition in the total mass of the catotelm, which continues to release $\mathrm{CO}_{2}$ and $\mathrm{CH}_{4}$ anaerobically and very slowly.

For 38 boreal peat cores (E. Gorham, J. A. Janssens, S. C. Zoltai, and R. S. Clymo, unpublished manuscript) whose diverse basal ${ }^{14} \mathrm{C}$ dates have been treated as coming from a single peat profile (thereby assuming constancy of $p$ and $\alpha$ over both space and time), $p=$ $80 \mathrm{~g} \cdot \mathrm{m}^{-2} \cdot \mathrm{yr}^{-1}$ and $\alpha=0.00014$. If these values are applied to an average peat depth of $2.3 \mathrm{~m}$ (Table 1), and assumptions are made of bulk density $=112 \mathrm{~g} / \mathrm{L}$ and carbon fraction $=0.517$, then the current carbon accretion rate becomes $23 \mathrm{~g} \cdot \mathrm{m}^{-2} \cdot \mathrm{yr}^{-1}$. Over a total area of $3.30 \times 10^{12} \mathrm{~m}^{2}$ this becomes $0.076 \mathrm{Pg} / \mathrm{yr}$. This same model, with the same assumptions, yields an average age for these peat deposits of $4300 \mathrm{yr}$. Divided into $2.3 \mathrm{~m}$ depth, this results in an overall peat accumulation rate of $0.53 \mathrm{~mm} / \mathrm{yr}$, very similar to that derived from the data in Table 2.

There is a further question, whether individual peatlands are spreading laterally or, alternatively, are contracting in area. Although erosion and gullying do damage some peatlands, most often those subjected to human disturbance, there is no evidence for major contractions in the area of undisturbed peatlands. The evidence for present expansion is scanty, and some boreal peatlands have shown very little increase in recent millennia (Malmström 1923). According to Sjörs (1982) the main period of peatland spreading (paludification) was between 5000 and 2000 yr BP. However, Neustadt (1984), taking the large $\left(2268 \mathrm{~km}^{2}\right)$ Bakchar Bog in Western Siberia as typical and assuming an accretion rate of $0.5 \mathrm{~mm} / \mathrm{yr}$ (Neyshtadt et al. 1974), suggests that spreading has continued fairly rapidly up to the present time (Table 3). During the early Holocene in west-central Canada, fens and extensive peat 
TABLE 3. Spreading of the Bakchar Bog in Western Siberia during postglacial time (Neustadt 1984).

\begin{tabular}{ccc}
\hline \hline Period (yr BP) & Area $\left(\mathrm{km}^{2}\right)$ & Increase $\left(\mathrm{km}^{2}\right)$ \\
\hline 8000 & 32 & 333 \\
6000 & 365 & 642 \\
4000 & 1007 & 801 \\
2000 & 1808 & 460 \\
0 & 2268 & \\
\hline
\end{tabular}

accumulation occurred only in the Rocky Mountain foothills and north of $\approx 53^{\circ} 30^{\prime} \mathrm{N}$. In middle and late Holocene (after $\approx 6000 \mathrm{yr} \mathrm{BP}$ ) such fens expanded southward, probably in response to declining climatic aridity (Zoltai and Vitt 1990).

Net carbon flux to the atmosphere from drained boreal and subarctic peatlands is more difficult to estimate because of the extreme paucity of data. According to Silvola (1986), undisturbed Finnish peatlands tend to release $\mathrm{CO}_{2}$ at the rate of $100-150 \mathrm{mg} \cdot \mathrm{m}^{-2} \cdot \mathrm{h}^{-1}$ at summer temperatures of $10^{\circ}-15^{\circ} \mathrm{C}$. Lowering the water table in one such peatland from the undrained range of $0-10 \mathrm{~cm}$ to the drained range of $40-60 \mathrm{~cm}$ beneath the surface increased the $\mathrm{CO}_{2}$ output within a few weeks to $300-400 \mathrm{mg} \cdot \mathrm{m}^{-2} \cdot \mathrm{h}^{-1}$, where it remained for $3 \mathrm{yr}$. (Quite similar results have been reported in experimental peat cores by Moore and Knowles 1989.) In the year following drainage, the organic-matter equivalent of $\mathrm{CO}_{2}$ release was estimated as $\approx 700$ $\mathrm{g} \cdot \mathrm{m}^{-2} \cdot \mathrm{yr}^{-1}$, or (assuming that carbon content $=51.7 \%$ ) a carbon equivalent of $362 \mathrm{~g} \cdot \mathrm{m}^{-2} \cdot \mathrm{yr}^{-1}$. Taking this value as characteristic (drainage for forestry accounts for $\approx 77 \%$ of total drainage in the countries listed in Table 1, according to Kivinen and Pakarinen 1981), the total release of carbon by drainage of boreal and subarctic peatlands would be $\left(0.115 \times 10^{12} \mathrm{~m}^{2}\right) \times(362$ $\left.\mathrm{g} \cdot \mathrm{m}^{-2} \cdot \mathrm{yr}^{-1}\right)=0.042 \times 10^{15} \mathrm{~g} / \mathrm{yr}$, or $0.042 \mathrm{Pg} / \mathrm{yr}$. This is a substantial fraction (55\%) of the carbon just estimated to be sequestered currently by undrained peatlands. However, releases over the longer term may be very much less. According to Armentano and Menges (1986), carbon release from Finnish/Soviet peatlands drained for pasturing and forestry for many decades is only $\approx 30 \mathrm{~g} \cdot \mathrm{m}^{-2} \cdot \mathrm{yr}^{-1}$. Drainage for crops is estimated to release $217 \mathrm{~g} \cdot \mathrm{m}^{-2} \cdot \mathrm{yr}^{-1}$. Applying these figures, weighted for the areas drained for forestry and agriculture in Finland and the USSR (the leading countries in total areas of peatland drainage [Kivinen 1980]) yields a mean long-term carbon release rate of 74 $\mathrm{g} \cdot \mathrm{m}^{-2} \cdot \mathrm{yr}^{-1}$. Taking this value, the total release of carbon by long-term drainage of boreal and subarctic peatlands would be only $0.0085 \mathrm{Pg} / \mathrm{yr}$, about one-fifth of the $0.042 \mathrm{Pg}$ estimated using a short-term release rate. The true release rate should presumably lie somewhat above the lower estimate.

The utilization of peat for fuel releases yet more carbon dioxide to the atmosphere. According to Kivi- nen $(1980)$, the USSR produces $\approx 100 \times 10^{6}$ tons (megagrams) of fuel peat ( $40 \%$ water) annually, with Finland the only other significant boreal-subarctic producer at $1.5 \times 10^{6}$ tons. Botch and Masing (1983), however, claim that Soviet fuel peat production is only $60-65 \times 10^{6}$ tons/yr and declining. Averaging these two estimates for the USSR, the annual carbon release from fuel peat is $\left(82.75 \times 10^{12} \mathrm{~g}\right) \times(0.60$ [ = fraction dry mass $]) \times(0.517[=$ fraction carbon $])=0.026 \mathrm{Pg} /$ yr.

Net flux of $\mathrm{CH}_{4}$ from boreal and subarctic peatlands to the atmosphere is also difficult to estimate. Data are scarce, tend to be logarithmically distributed, and do not include fluxes by ebullition (Harriss et al. 1985). Addition of tower and airplane measurements, on a much larger scale than current flux-chamber measurements, may improve spatial estimates. They are currently being tested by scientists with NASA support. $\mathrm{CH}_{4}$ estimates are affected strongly by temperature (Crill et al. 1988, Whalen and Reeburgh 1988) and depth of water table (Harriss et al. 1982, Sebacher et al. 1986; N. B. Dise, personal communication). Nevertheless, data compiled by Crill et al. (1988) (Table 4) show rather little variation in peak midsummer carbon fluxes (means of 96 to $188 \mathrm{mg} \cdot \mathrm{m}^{-2} \cdot \mathrm{d}^{-1}$ ) over a range from $26^{\circ}$ to $62^{\circ} \mathrm{N}$ latitude, the lowest value coming from Florida and the highest from the mountains of West Virginia. Variation in water table depth is probably an important confounding factor in these sites. Distinctly lower peak carbon flux values $\left(23\right.$ and $\left.46 \mathrm{mg} \cdot \mathrm{m}^{-2} \cdot \mathrm{d}^{-1}\right)$ are given for northern sites $\left(65^{\circ}\right.$ and $\left.56^{\circ} \mathrm{N}\right)$ by Whalen and Reeburgh (1988) and by Moore and Knowles (1987). By far the largest data base comes from Minnesota (Crill et al. 1988), and if we employ half that peak carbon emission rate of $155 \mathrm{mg} \cdot \mathrm{m}^{-2} \cdot \mathrm{d}^{-1}$ for an average of $180 \mathrm{~d} / \mathrm{yr}$ above $0^{\circ}$ (Gorham 1988), $\mathrm{CH}_{4}-\mathrm{C}$ emissions from undrained boreal and subarctic peatlands would amount to $\left(3.30 \times 10^{12} \mathrm{~m}^{2}\right) \times(0.0775$ $\left.\mathrm{g} \cdot \mathrm{m}^{-2} \cdot \mathrm{d}^{-1}\right) \times(180 \mathrm{~d})=0.046 \mathrm{Pg} / \mathrm{yr}$. This is almost the same as the estimate by Matthews and Fung (1987), using quite different methods, for wetlands between $50^{\circ}$ and $70^{\circ} \mathrm{N}$.

The various carbon fluxes, and the total carbon stock, are summarized in Table 5. It appears that the amount of carbon released as $\mathrm{CO}_{2}$ from northern peat deposits to the atmosphere owing to drainage and peat com-

TABLE 4. Carbon flux as methane in midsummer along a latitudinal gradient (from Crill et al. 1988).

\begin{tabular}{lccc}
\hline \hline Location & $\begin{array}{c}\text { Latitude } \\
\left({ }^{\circ} \mathrm{N}\right)\end{array}$ & $\begin{array}{c}\text { Number of } \\
\text { samples }\end{array}$ & $\begin{array}{c}\text { Methane- } \\
\text { carbon flux } \\
\left(\mathrm{mg} \cdot \mathrm{m}^{-2} \cdot \mathrm{d}^{-1}\right)\end{array}$ \\
\hline Florida & 26 & 11 & 96 \\
Georgia & 30 & 12 & 106 \\
W. Virginia & 39 & 14 & 188 \\
Minnesota & 47 & 179 & 155 \\
Alaska & 62 & 13 & 147 \\
\hline
\end{tabular}


bustion $(0.035 \mathrm{Pg})$ is less than one-half of the current amount added annually to the peat in undrained boreal and subarctic fens and bogs $(0.076 \mathrm{Pg})$. Carbon released from those same undrained peatlands as $\mathrm{CH}_{4}$, although only $61 \%$ of the amount currently fixed by peat accumulation, has a much greater climatic significance. Multiplied by a factor of 20 to take account of its greater effectiveness as a "greenhouse" gas (Mooney et al. 1987), the release of $\mathrm{CH}_{4}-\mathrm{C}$ would be equivalent to a release of $0.92 \mathrm{Pg}$ of $\mathrm{CO}_{2}-\mathrm{C}$, more than an order of magnitude greater than the amount of $\mathrm{CO}_{2}-\mathrm{C}$ currently fixed by peat deposition, and about 26 times that released by drainage and peat-fuel combustion. Whether such a multiplication factor is justified has recently been questioned by Lashof and Ahuja (1990), who point out that the residence time of $\mathrm{CH}_{4}$ in the atmosphere (14.4 yr) is much shorter than that of $\mathrm{CO}_{2}(230 \mathrm{yr})$. They estimate that the global warming potential of $\mathrm{CH}_{4}$ may only be $\approx 3.7$ times that of $\mathrm{CO}_{2}$ on a molar basis. The shorter residence time of $\mathrm{CH}_{4}$ reflects its greater chemical reactivity in the atmosphere, which may have side effects not presently calculable.

\section{MAJOR UNCERTAINTIES IN ESTIMATES OF STOCKS AND FLUXES}

The data bases for both stocks and fluxes are inadequate in almost every way, partly because peatlands have received proportionately little attention from ecologists and biogeochemists as compared to forests, grasslands, and aquatic ecosystems. Fortunately, peatland vegetation and landforms are relatively similar in North America and Eurasia (compare Sjörs 1961, 1963, Walter 1977, Glaser et al. 1981, and Wheeler et al. 1983), so that generalizations from one continent to another are quite reasonable.

\section{Carbon stock}

Three major deficiencies exist in measurements of carbon stocks in peatlands; they concern estimates of both area and depth of peat, and also its bulk density. These deficiencies can be illustrated with reference to the two countries that contain by far the largest areas of peatland, the USSR and Canada.

The estimate of Canadian peatland area (Fig. 1) is based on inventories taken by government agencies but, in northern Canada especially, these inventories are often either broad-scale or lacking (Tarnocai 1984). In Canada peatlands are defined as having a minimum 40-cm peat depth (Tarnocai 1984), whereas elsewhere a 30-cm depth is usually definitive (Kivinen and Pakarinen 1981). To convert, rather crudely, the Canadian data to a $30-\mathrm{cm}$ depth limit, I have added one-quarter of the area of Canadian wetlands that are shallower than $40 \mathrm{~cm}$ (Zoltai 1988), and assumed their mean depth to be $35 \mathrm{~cm}$.

The mean depth of Canada's peatlands is also not securely founded, thousands of measurements being taken as representative of millions of hectares without
TABLE 5. Present net carbon fluxes to and from boreal and subarctic peatlands, and the current carbon stock, in petagrams $\left(1 \mathrm{Pg}=10^{15} \mathrm{~g}\right)$.

\begin{tabular}{lc}
\hline \hline Undrained peatlands (Area $\left.3.30 \times 10^{12} \mathrm{~m}^{2}\right)$ & $\begin{array}{c}\text { Carbon flux } \\
(\mathrm{Pg} / \mathrm{yr})\end{array}$ \\
Accumulated as organic carbon in peat & 0.096 \\
Overall & 0.076 \\
Current & 0.046 \\
Released as $\mathrm{CH}_{4}$ to atmosphere & Carbon flux \\
Drained peatlands (Area $\left.0.115 \times 10^{12} \mathrm{~m}^{2}\right)$ & 0.0085 \\
& 0.026 \\
Released as $\mathrm{CO}_{2}$ by long-term drainage & Carbon stock \\
Released as $\mathrm{CO}_{2}$ by fuel combustion & $(\mathrm{Pg})$ \\
All unmined peatlands (Area $\left.3.42 \times 10^{12} \mathrm{~m}^{2}\right)$ & 455 \\
\hline
\end{tabular}

any effort at stratified random sampling. My estimate of $2.2 \mathrm{~m}$ is lower than the $2.7 \mathrm{~m}$ calculated from data compiled by Tarnocai (1984), in particular because his estimates for the large areas of peatland in Ontario and Quebec are distinctly higher than those given by J. L. Riley (1987a and personal communication), and Boville et al. (n.d.).

The area of Soviet peatlands (Fig. 2) is much more poorly known, or if known, is not readily accessible. Kivinen and Pakarinen (1981) estimate it, without much explanation, at $150 \times 10^{6} \mathrm{ha}$, but according to Sabo (1980) the total wetland area (excluding tundra and forest-tundra) is $245 \times 10^{6}$ ha (cf. Neustadt 1984). The wetland/peatland quotient resulting from these two estimates is 1.6 , much higher than the quotient of 1.1 for Canadian peatlands (data of Zoltai 1988).

The mean depth of Soviet peatlands is also not well established. Neustadt (1984) indicates that in the major peat bogs it is "usually not greater than 3 to $4 \mathrm{~m}$." In the belt of intensive peat accumulation he states that it averages $2.2 \mathrm{~m}$, being considerably less $(1.0-1.5 \mathrm{~m})$ in regions with fewer peatlands. I have, therefore, estimated the overall mean depth conservatively at $2.5 \mathrm{~m}$.

The bulk density of peat can vary widely both from place to place and within a single peat core. I have used (Gorham 1988) a mean figure of $112 \mathrm{~g} / \mathrm{L}$ for Canadian peats, derived from extensive data sets of Tarnocai (1984), Boville et al. (n.d.), Riley (1987a,b), Riley and Michaud (1987), and E. Gorham and J. A. Janssens, (unpublished manuscript). As far as I know, mean data not been calculated for the USSR or for Fennoscandia, nor have I located any large data bases.

During the years to come it will be especially. important to measure, by satellite imagery, changes in the area of boreal and subarctic peatlands, because climate change is likely to destroy them in some regions while stimulating their spread in others.

It may be noted as a final point that data on total live biomass (above- plus belowground) in boreal and 


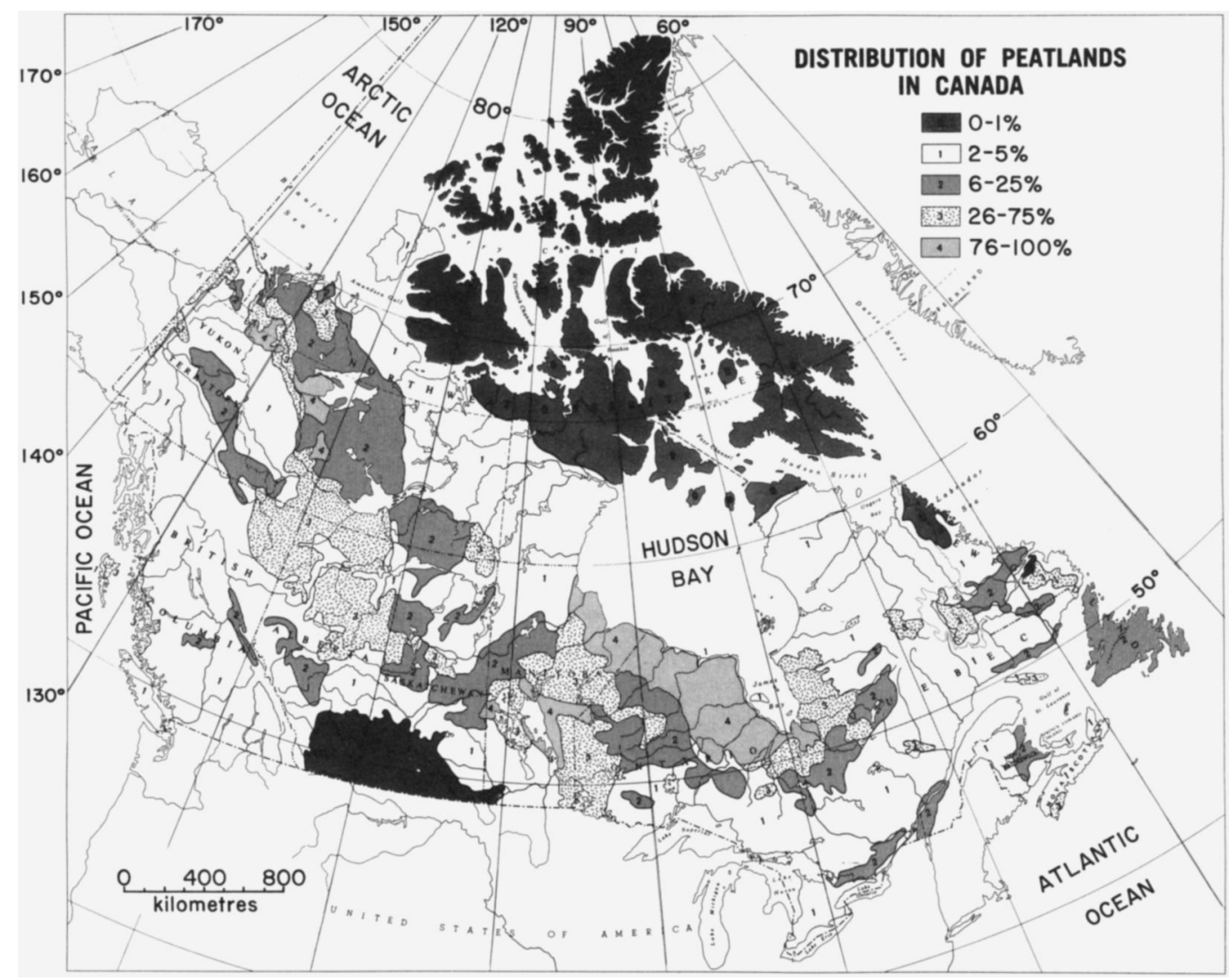

FIG. 1. The location of Canada's peatland resources (modified from Tarnocai 1984).

subarctic peatlands are also very scarce. My calculations dealt with only 14 values compiled by Bradbury and Grace (1983) and Grigal et al. (1985).

\section{Carbon fluxes}

Present rates of accumulation of carbon in peat deposits cannot readily be measured because of the slowness of the decay process. Comparisons of annual gains and losses of carbon from three tundra and taiga ecosystems (Billings 1987) suggest that carbon accumulation can account for $6-60 \%$ of net primary production. As noted earlier, however, decay may go on anaerobically for hundreds or even thousands of years, so that dating of shallow peat cores, itself not easy to do and currently the subject of intensive investigation (N. R. Urban, personal communication), may yield results that are much too high. Even long-term mean rates over thousands of years are not often calculated; we have been able to gather only 138 basal ${ }^{14} \mathrm{C}$ dates for our work on boreal and subarctic peatlands in North America (E. Gorham, J. A. Janssens, S. C. Zoltai, and R. S. Clymo, unpublished manuscript). Far fewer cores are available with multiple dates. Of these some yield more or less linear age/depth curves, suggesting relatively constant rates of accretion. Others are clearly curvilinear and consistent with Clymo's (1984) model of decreasing peat accumulation over time.

Rates of release of $\mathrm{CO}_{2}$ and $\mathrm{CH}_{4}$ from drained peatlands require a great deal more study in relation to regional temperature and precipitation, and especially to the degree of drawdown of the water table by drainage. Data are very scarce; those available are reviewed by Armentano and Menges (1986). It will be of particular value to examine the balance between drawdown owing to local permafrost melting and thermokarst erosion, and flooding owing to the formation of thaw lakes; the effects of these phenomena upon $\mathrm{CO}_{2}$ and $\mathrm{CH}_{4}$ emissions are likely to be of great importance as the climate warms. Experimental manipulation of permafrost sites could be very useful in this context.

Clearly the rate of Soviet (and other) peat-fuel combustion needs to be established more accurately, given the disagreement between Kivinen (1980) and Botch and Masing (1983).

Methane emissions by undrained peatlands are being given increasing attention, but are among the least certain of the estimates in this review; much greater efforts should be made to study both regional and vegetational differences. More measurements are needed throughout the ice-free season along the latitudinal gradient 


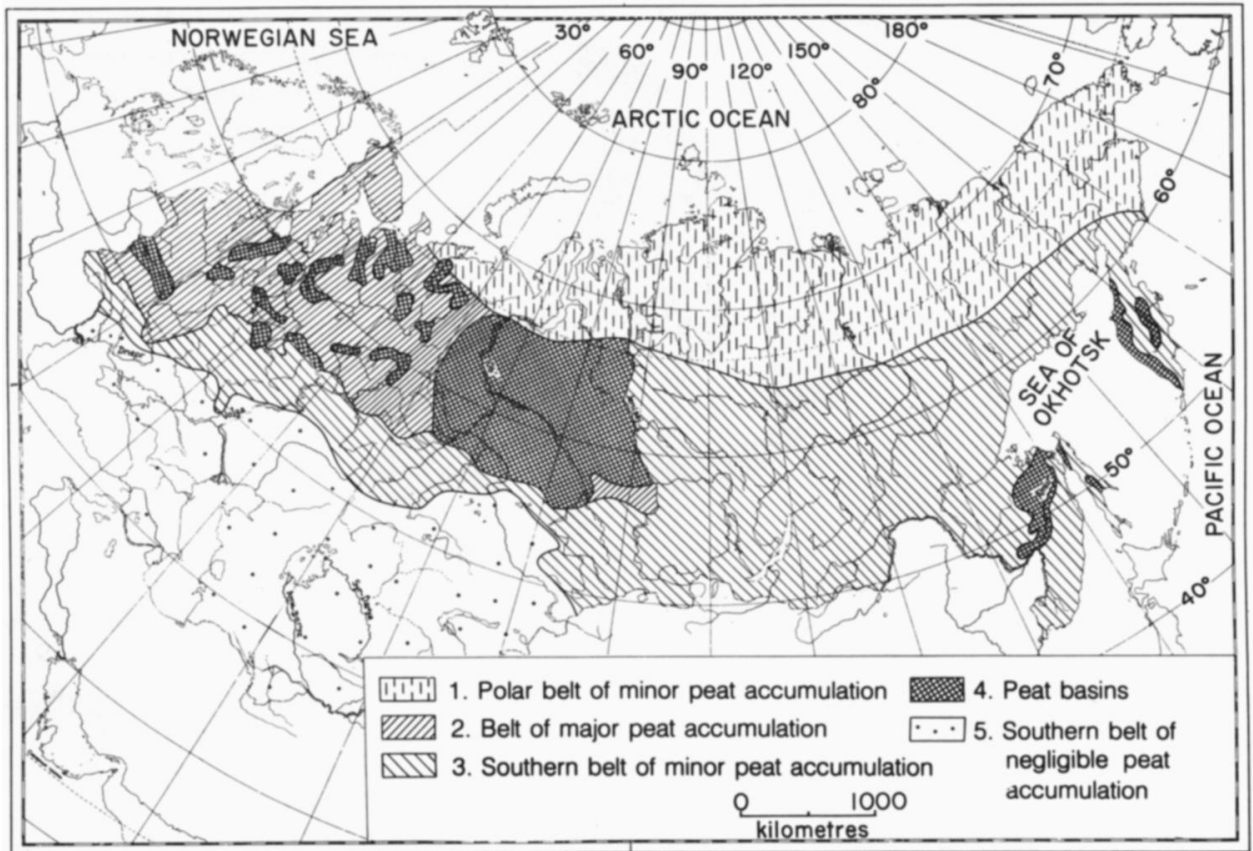

Frg. 2. The location of Soviet peatland resources (modified from Neustadt 1984).

(cf. Crill et al. 1988) in relation to both temperature and water table depth. Comparisons of open-water areas (presently very little investigated) with adjacent wet sedge fens and drier Sphagnum bogs should certainly be made in major peatlands such as those of the Hudson/James Bay Lowland (Riley 1982). Data from the Red Lake Peatland in Minnesota (Crill et al. 1988) indicate that in midsummer sedge fens emit substantially more methane $\left(325 \mathrm{mg} \cdot \mathrm{m}^{-2} \cdot \mathrm{d}^{-1}\right)$ than forested bogs $\left(130 \mathrm{mg} \cdot \mathrm{m}^{-2} \cdot \mathrm{d}^{-1}\right)$ and open bogs $\left(85 \mathrm{mg} \cdot \mathrm{m}^{-2}\right.$. $\left.\mathrm{d}^{-1}\right)$. At present the areas of fen and bog in that peatland are similar (P. H. Glaser, personal communication), but in the past the ratio of fen to bog has varied considerably (Janssens et al. 1990). The influence of vegetation type upon $\mathrm{CH}_{4}$ emissions has also been observed in Canada (S. E. Bayley, personal communication).

The relationship of $\mathrm{CH}_{4}$ emissions to the depth (or height) of the water table deserves particular attention, both in the field and experimentally (cf. Harriss et al. 1982, Sebacher et al. 1986, Moore and Knowles 1989). In this connection, field experiments have shown that maintaining the water table artificially at the peat surface keeps $\mathrm{CH}_{4}$ emissions distinctly above those where the water table is allowed to decline naturally over the summer (N. B. Dise, personal communication).

It is especially important to assess the influence of changing water tables, to be expected as a major consequence of climate warming, upon the balance between $\mathrm{CO}_{2}$ and $\mathrm{CH}_{4}$ fluxes. Both are important greenhouse gases, and as water tables fall $\mathrm{CO}_{2}$ emissions may be expected to increase substantially while those of $\mathrm{CH}_{4}$ decline sharply. Moore and Knowles (1989) have shown in experimental laboratory studies of peat cores that the molar ratio of $\mathrm{CO}_{2}$ to $\mathrm{CH}_{4}$ (Fig. 3) may rise from as low as 10 with the water table $10 \mathrm{~cm}$ above the peat, not uncommon in many fens, to $>10000$

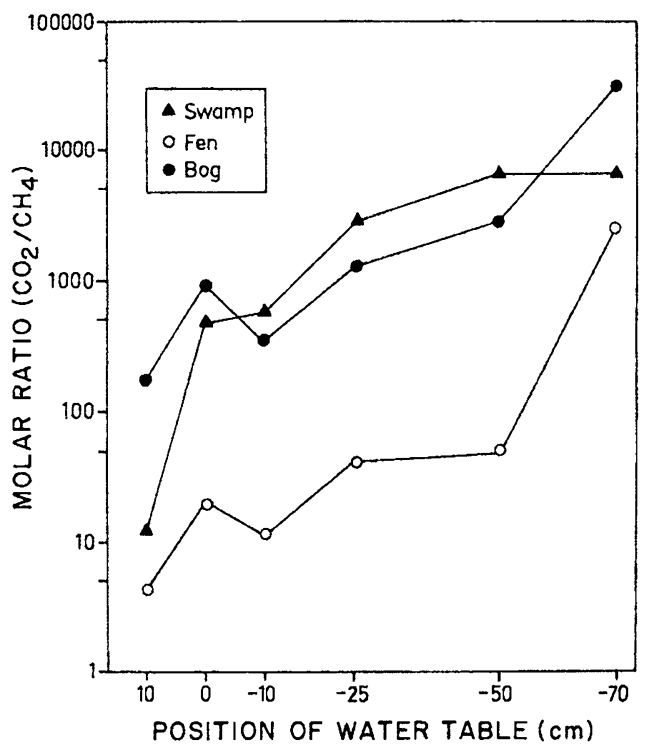

FIG. 3. The influence of water table level (relative to the upper peat surface) upon the molar ratio of emissions of carbon dioxide to those of methane from peat columns in the laboratory (modified from Moore and Knowles 1989). 
when the water table is $70 \mathrm{~cm}$ below the peat surface. The latter condition can be attained under artificial drainage, but also during severe natural droughts near the southern border of boreal peatlands (Verry 1984). A $10-\mathrm{cm}$ drop in water table, easily envisaged under "greenhouse" warming, could thus exert a strong depressing effect upon methane emissions.

It must be noted that in undisturbed peatlands the $\mathrm{CO}_{2}$ emitted during decomposition will have been derived earlier from the atmosphere. It will also be slightly less than the amount fixed from the atmosphere by photosynthesis, $\approx 8-9 \%$ of net primary production being stored in the peat (Gorham 1988, 1990).

\section{Probable Responses to Climate Change}

The preparation of plausible scenarios for the responses of peatlands to climate change must involve a great variety of considerations, for instance direct controls of peatland processes (production, decomposition, and storage of organic matter) by increased $\mathrm{CO}_{2}$ and temperature, indirect controls by carbon/nutrient interactions and by altered hydrology and thermokarst erosion, increased accumulation of live plant biomass, possible involvement of the entire peat profile in carbon loss, the role of fire, and ultimately the topographic control of peat formation. Altered relationships to connected aquatic ecosystems, and export to those ecosystems, also deserve attention. Let us take up these considerations one by one.

\section{Direct climatic controls}

Houghton and Woodwell (1989) have suggested that increasing temperature is likely to increase plant respiration to a much greater degree than photosynthesis. It is also likely to increase microbial and fungal respiration, thus increasing $\mathrm{CO}_{2}$ release to the atmosphere. The only available evidence on direct effects of increased atmospheric $\mathrm{CO}_{2}$ and temperature on peatlands is provided by Billings et al. (1982, 1983, 1984), who placed intact cores of wet coastal-tundra peat from Barrow, Alaska, under controlled conditions in a phytotron. Doubling $\mathrm{CO}_{2}$ from 400 to $800 \mu \mathrm{L} / \mathrm{L}$ over a simulated growing season at $8^{\circ} \mathrm{C}$ (including altered photoperiods) increased carbon capture in this ecosystem by $57 \%$ when the water table was maintained at the surface (Billings et al. 1983). However, another experiment showed that carbon capture at $8^{\circ}$ (the predicted July mean for Barrow under simulated climate warming) was $15 \%$ less than that at $4^{\circ}$ (the present July mean at Barrow), again with the water table at the surface (Billings et al. 1982). Still other experiments showed that lowering the water table by 5 or $10 \mathrm{~cm}$ strongly decreased carbon capture; in the latter case the tundra cores were actually converted from sinks to sources for atmospheric carbon over the growing season. A $10-\mathrm{cm}$ decline in peatland water tables seems not unlikely as the projected climate warming takes place; in a small northern Minnesota bog it would be equivalent to a decline from the mean annual minimum level to the nondrought minimum observed over $20 \mathrm{yr}$ (Verry 1984). During the severe drought of 1976 the minimum level fell $53 \mathrm{~cm}$ below the mean annual minimum.

Studies of the kind undertaken by Billings et al. should be extended over a wide range of peat types and environmental conditions. They should also include emissions of $\mathrm{CH}_{4}$ along with those of $\mathrm{CO}_{2}$.

The strong seasonal cycle of $\mathrm{CH}_{4}$ emission (Crill et al. 1988, Whalen and Reeburgh 1988; N. B. Dise, personal communication) suggests that rising temperature could increase $\mathrm{CH}_{4}$ emissions substantially. Although the data compiled by Crill et al. (1988) show little sign of any midsummer-emissions gradient reflecting the latitudinal gradient in summer temperature (Table 4), the longer ice-free season at southern latitudes will increase total annual emissions even if peak emissions are unaffected. The matter clearly deserves further study.

Another likely effect of higher temperatures will be to shift the zone of peat formation (and the zone of forested peatlands) northward (cf. Miller 1981). Zoltai and Pollett (1983, see also Zoltai and Tarnocai 1975) point out that in Arctic Canada peat formation was common 8500-9000 yr BP, whereas peat seldom accumulates there now. They suggest that the climate was warmer then, and that peat formation ceased owing to climatic cooling and strong development of permafrost. Presumably climatic warming would reverse this situation. At the same time peatlands at the southern boundary of the boreal zone, for instance the large Red Lake Peatland in northwest Minnesota (Glaser et al. 1981, Wheeler et al. 1983), where peat has accumulated unusually rapidly (Gorham 1987), would be likely to shift from being carbon sinks and become carbon sources if more frequent and extreme summer droughts (Manabe and Wetherald 1986, 1987; but see Mitchell and Warrilow 1987) were to cause a substantial drawdown of the water table and favor peat oxidation. These southern peatlands might also exhibit better tree growth and an increase of live biomass. During the drought of the 1930s tree-rings of black spruce and tamarack on Minnesota's peatlands widened considerably (Hofstetter 1969, Tilton 1975).

\section{Carbon/nutrient interactions}

For increased carbon capture to take place, additional nutrients that are limiting in peatlands (chiefly nitrogen and phosphorus) must be made available. To what degree higher temperatures and lowered water tables will cause mineralization of those nutrients presently locked up in peat remains to be established. According to Billings et al. (1984), addition of nitrogen increased net ecosystem uptake of $\mathrm{CO}_{2}$ by cores of Alaskan tundra peat. 


\section{Altered hydrology}

The degree of peat oxidation induced by falling water tables, and indirectly by climate warming, is likely to be exceedingly important, but it will also be extremely difficult to forecast, for a variety of reasons. The hydrology of large peatlands is complex (Ivanov 1981, Siegel 1983) and can be affected by the nature of the vegetation as well as by the pattern of peat deposition (Woo and Heron 1987). So far, global modeling of the influence of "greenhouse" climate warming upon soil moisture has been restricted to terrestrial soils (Manabe and Wetherald 1986, 1987, Mitchell and Warrilow 1987), and peat deposits may be expected to behave very differently.

Modelling the $\mathrm{CH}_{4}$ flux from a subarctic fen under a $2 \times \mathrm{CO}_{2}$ (doubling of atmospheric $\mathrm{CO}_{2}$ ) climate scenario (N. T. Roulet, T. R. Moore, and P. La Fleur, personal communication) suggests that in such ecosystems the summer water table would fall sufficiently to more than offset the expected increase in $\mathrm{CH}_{4}$ flux induced by higher temperatures.

Permafrost underlies a great many subarctic and boreal peatlands (Fig. 4 shows permafrost distribution in Canada, and may be compared with Fig. 1 for peatland distribution there.) In the West Siberian Plain permafrost extends south nearly to $59^{\circ} \mathrm{N}$ latitude (Baulin et al. 1984), and encompasses a good deal of the largest peatland in the world (Fig. 2). The effects of climatic warming upon permafrost (Lachenbruch and Marshall 1986) are likely to have profound consequences for the peatlands in which it occurs. Rapid runoff of water released from melting permafrost may exacerbate the fall in water tables to be expected from higher temperatures and increased evapotranspiration from larger standing crops of vegetation. This will favor release of $\mathrm{CO}_{2}$ by peat oxidation, particularly in the upper horizons (Farrish and Grigal 1988). It is also likely to inhibit $\mathrm{CH}_{4}$ emission (Harriss et al. 1982, Sebacher et al. 1986, Moore and Knowles 1989), perhaps by decreasing $\mathrm{CH}_{4}$ production as the water table falls to depths where recently deposited and labile organic matter is less available, but probably also by increasing the depth of the peat column habitable by $\mathrm{CH}_{4}$-oxidizing bacteria. If water tables are drawn down substantially, peatlands may actually become sinks for atmospheric $\mathrm{CH}_{4}$, converting it into microbial biomass as well as the much less effective "greenhouse" gas, $\mathrm{CO}_{2}$ (Harriss et al. 1982, Whalen and Reeburgh 1990).

Melting of permafrost is also likely to increase substantially the proportion of northern peatlands drained by thermokarst erosion (Billings et al. 1982, 1983, Billings and Peterson 1990). It will also lead to the formation of shallow thaw lakes from whose stirred-up, oxidizing organic sediments $\mathrm{CO}_{2}$ will be released. However, many shallow thermokarst basins will eventually be colonized by sedges, and later by Sphagnum mosses and heaths (Drury 1956, Luken and Billings 1983), which will renew the sequestration of $\mathrm{CO}_{2}$ in peat and the emission of $\mathrm{CH}_{4}$ from it. The balance, under scenarios of climatic warming, between accelerated peat oxidation (and reduced $\mathrm{CH}_{4}$ emission) in intact but drier peatland surfaces and restored peat accumulation (and $\mathrm{CH}_{4}$ emission) in flooded and recolonized thermokarst basins cannot at present be predicted. It should have high priority for investigation, both by comparative studies and by experiments.

\section{Accumulation of live plant biomass}

It is likely that live plant biomass in peatlands will increase with rising summer temperatures, as does the dry biomass of pure stands of sedges, which increases from $\approx 200 \mathrm{~g} / \mathrm{m}^{2}$ at a midsummer temperature of $8^{\circ}$ to $\approx 500 \mathrm{~g} / \mathrm{m}^{2}$ at $16^{\circ}$ and almost $900 \mathrm{~g} / \mathrm{m}^{2}$ at $20^{\circ}$ (Gorham 1974). However, for nonwoody plants most of that biomass will be decomposed annually.

Temperature effects upon woody biomass that accumulates over the long term may be of much greater importance, but available data do not allow a clear separation from the indirect effects of a warmer climate operating through drawdown of the water table. The available data do indicate a broad range of overstory biomass in peatlands, from as little as $460 \mathrm{~g} / \mathrm{m}^{2}$ in a Finnish raised bog $\left(61^{\circ} \mathrm{N}\right)$ to as much as $13500 \mathrm{~g} / \mathrm{m}^{2}$ in a small kettle-hole bog in Minnesota $\left(47^{\circ} 30^{\prime} \mathrm{N}\right)$ within $200 \mathrm{~km}$ of the forest/prairie border (Grigal et al. 1985). Moreover, data from Minnesota indicate a substantial increase in the width of black spruce and tamarack growth-rings during the drought of the 1930s (Hofstetter 1969, Tilton 1975). Such an increase was also evident during the dry summers of 1976 and 1977 (K. J. Vogel, personal communication), owing probably to improved root aeration and also to increased mineralization of limiting nutrients such as nitrogen and phosphorus from newly re-aerated peat. However, where severe drawdown occurs in extremely nutrientlimited peatlands, live biomass may not increase and may even decrease. As shown by Tamm $(1951,1965)$ and Malmström (1952), after severe draining of the Swedish peatland Norra Hällmyren, a community of Scirpus caespitosus with Eriophorum vaginatum, Sphagnum mosses, and Calluna vulgaris was replaced by a depauperate community of Andromeda polifolia, Polytrichum mosses, and Cladonia lichens. Only where wood ash was applied as fertilizer did vigorously growing, self-sown trees take over the peatland.

\section{Carbon loss throughout the peat profile}

According to Clymo $(1984,1987)$ the existence of a distinct gradient of increasing $\mathrm{CH}_{4}$ concentration with depth in peat deposits indicates that anaerobic decomposition goes on slowly throughout the entire peat profile. If that is so, $\mathrm{CH}_{4}$ production will not cease, though it may decrease substantially, as water tables fall. However, falling water tables could well result in the $\mathrm{CH}_{4}$ oxidizing bacteria that inhabit aerobic peats scavenging all of the $\mathrm{CH}_{4}$ produced in the remaining anaerobic 

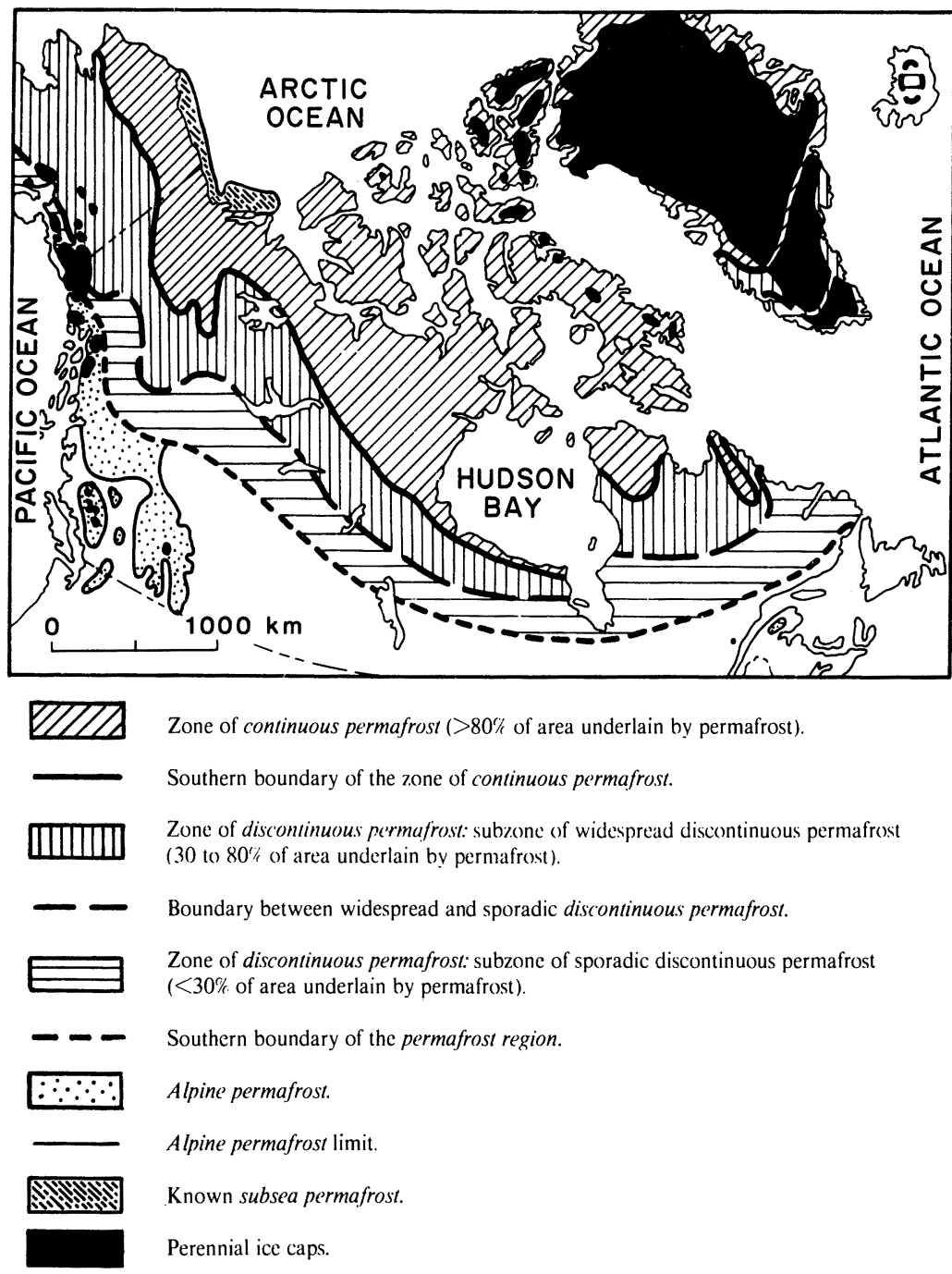

FIG. 4. Permafrost zones in North America (modified from Harris et al. 1988).

zone, and even some atmospheric $\mathrm{CH}_{4}$ (Harriss et al. 1982, Whalen and Reeburgh 1990). It should be noted that the marked seasonality of $\mathrm{CH}_{4}$ emission (Crill et al. 1988, Whalen and Reeburgh 1988; N. B. Dise, personal communication) suggests that evolution of $\mathrm{CH}_{4}$ by the decomposition of deep peat is relatively unimportant. However, ${ }^{14} \mathrm{C}$-dating of $\mathrm{CH}_{4}$ emissions from peatlands indicates that some old carbon must come from such a source (Wahlen et al. 1989). More work along these lines is clearly needed.

\section{Fire}

The role of fire, expected to increase substantially as climate warms (Clark 1988, Franklin et al. 1990), must also be considered as a factor in releasing stored carbon to the atmosphere. Fire scars are often visible in peatlands (Glaser et al. 1981), as are charcoal layers in peat (Robinson 1987). However, fires are likely to occur on peatlands much less frequently than on uplands, and estimates of the loss of peat in fires do not appear to be available.

Heinselman (1975) believes that fires may be important in retarding paludification. On the other hand, Walter (1977), reviewing the Russian literature, states that in West Siberia fire in upland forests can actually lead to paludification by allowing the establishment of Sphagnum obtusum and $S$. apiculatum on the newly burned surfaces, presumably because of the higher water tables favored by lower evapotranspiration.

\section{Connections to aquatic ecosystems}

Large northern peatlands are often dotted by shallow pools, ponds, and lakes (Gore 1983). According to Ivanov (1981: Table 18) there are hundreds of thousands of lakes $>0.5 \mathrm{ha}$ in the peatlands of the West Siberian Plain, with a mean size of 5-24 ha in different regions. 
Moreover, they account for $2-25 \%$ of the peatland area in these same regions. Whether they are a hydrological requirement in these very large organic landforms is not known. If not, these water bodies may well contract and in many cases disappear under a warming climate; they are not a feature of more southerly continental peatlands (Glaser and Janssens 1986) such as the large Red Lake Peatland near the forest/prairie border in northwest Minnesota (Glaser et al. 1981). Monitoring the extent of open water in areas such as the Hudson/ James Bay Lowland and the West Siberian Plain by satellite-radar technology might be an excellent method of detecting the early effects of climate warming upon boreal and subarctic peatlands.

The function of freshwater habitats in transferring old carbon from peat to aquatic food chains has been demonstrated by Schell (1983). Disappearance of such habitats under climate warming might be of considerable importance for the wildfowl that utilize these peatlands (Stroud et al. 1987).

\section{CONCLUSION}

Given the diversity of possible responses by boreal and subarctic peatlands to climatic warming, it is impossible at present to predict their future contributions to the global carbon cycle.

Perhaps the boreal and subarctic zones of peat accumulation will merely be shifted northward (cf. Zoltai and Vitt 1990 for southward movement in the midHolocene). Using the techniques of Geographic Information Systems in conjunction with General Circulation Models for climate change under a doubled "greenhouse" gas scenario, it should be possible to determine the future climatic limits for, say, the zone in which peatlands account for $>25 \%$ (or $75 \%$ ) of the land area in Canada (see Fig. 1), or the zones of peat basins and major peat accumulation in the USSR (see Fig. 2). Topographic limits for peat formation, i.e., slopes on the order of 1 in 1000 except in exceedingly oceanic climates, must also be taken into account, as well as the total amount of land actually available to the northward.

Alternatively, and perhaps more likely, the rapidity of "greenhouse" warming may be such that it causes degradation of southern peatlands much faster than northern peatlands can expand northward toward the shores of the Arctic Ocean. If climate warming were to have an effect equivalent to that of present longterm drainage for forestry and pasturing in Finland and the Soviet Union (Armentano and Menges 1986), i.e., release of $30 \mathrm{~g} \cdot \mathrm{m}^{-2} \cdot \mathrm{yr}^{-1}$ as $\mathrm{CO}_{2}$, then release of carbon from the total area of undrained peatlands $\left(3.30 \times 10^{12}\right.$ $\mathrm{m}^{2}$ ) would amount to $0.099 \mathrm{Pg} / \mathrm{yr}$. As an extreme possibility, let us calculate the amount of carbon released if peat ceased to accumulate world-wide and instead 1 $\mathrm{cm}$ of peat of mean bulk density were decomposed annually, on average, owing to falling water tables. (The amount might be zero or even negative at high lati- tudes, and much greater at low latitudes.) Given a mean peatland depth of $2.3 \mathrm{~m}, 1 \mathrm{~cm}$ amounts to $1 / 230$ of the total stock of $455 \mathrm{Pg}$ of peat carbon (Table 1), or $2.0 \mathrm{Pg}$. This would be more than one-third of current annual carbon release owing to fossil-fuel combustion, 5.6 Pg (Houghton and Woodwell 1989), and comparable to the carbon released by deforestation, 0.4-2.5 $\mathrm{Pg}$ (Houghton and Woodwell 1989). It must be borne in mind, however, that under these scenarios, there is likely to be a very substantial reduction in $\mathrm{CH}_{4}$ emissions.

Given the complexity of the issues raised here, it is clear that the possible influence of global warming upon the carbon cycle in boreal and subarctic peatlands merits an intensive (and expensive) research effort.

\section{ACKNOWLEDGMENTS}

I thank J. A. Janssens, S. C. Zoltai, R. S. Clymo, J. L. Riley, S. E. Bayley, W. D. Billings, N. T. Roulet, T. R. Moore, P. Lafleur, and G. R. Shaver for advice, assistance and access to unpublished manuscripts. This project was supported by the U.S. Department of Energy (Purchase Order No. 19X$3 \mathrm{C} 968 \mathrm{~V})$, the Andrew W. Mellon Foundation, and the National Science Foundation (BSR/LTER-07905407). The typescript has not been reviewed by the Department of Energy, and the views expressed are those of the author alone.

\section{Literature Cited}

Aaby, B. 1986. Paleoecological studies of mires. Pages 145164 in B. E. Berglund, editor. Handbook of Holocene palaeoecology and palaeohydrology. John Wiley \& Sons, New York, New York, USA.

Armentano, T. V., and E. S. Menges. 1986. Patterns of change in the carbon balance of organic-soil wetlands of the temperate zone. Journal of Ecology 74:755-774.

Baulin, V., Y. B. Belopukhova, and N. S. Danilova. 1984 Holocene permafrost in the USSR. Pages 87-91 (Chapter 10) in A. A. Velichko, editor. Late Quaternary environments of the Soviet Union. University of Minnesota Press, Minneapolis, Minnesota, USA.

Billings, W. D. 1987. Carbon balance of Alaskan tundra and taiga ecosystems: past, present and future. Quaternary Science Reviews 6:165-177.

Billings, W. D., J. O. Luken, D. A. Mortensen, and K. M. Peterson. 1982. Arctic tundra: a source or sink for atmospheric carbon dioxide in a changing environment? Oecologia (Berlin) 53:7-11.

Billings, W. D., J. O. Luken, D. A. Mortensen, and K. M. Peterson. 1983. Increasing atmospheric carbon dioxide: possible effects on arctic tundra. Oecologia (Berlin) 58:286289.

Billings, W. D., J. O. Luken, D. A. Mortensen, and K. M. Peterson. 1984. Interaction of increasing atmospheric carbon-dioxide and soil-nitrogen in the carbon balance of tundra microcosms. Oecologia (Berlin) 65:26-29.

Billings, W. D., and K. M. Peterson. 1990. Some possible effects of climatic warming on arctic tundra ecosystems of the Alaskan North Slope. In R. L. Peters and T. Lovejoy, editors. Consequences of the greenhouse effect for biological diversity. Yale University Press, New Haven, Connecticut, USA, in press.

Botch, M. S., and V. V. Masing. 1983. Mire ecosystems in the U.S.S.R. Pages 95-152 in A. J. P. Gore, editor. Ecosystems of the world, 4B. Mires: swamp, bog, fen and moor, Regional studies. Elsevier, Amsterdam, The Netherlands.

Boville, B. W., R. E. Munn, and F. K. Hare. n.d. The storage of non-living carbon in boreal and Arctic zones-Canada. 
United States Department of Energy (DE-AS01-81EV10688), Washington, D.C., USA.

Bradbury, I. K., and J. Grace. 1983. Primary production in wetlands. Pages 285-310 in A. J. P. Gore, editor. Ecosystems of the world, 4A. Mires: swamp, bog, fen and moor. General studies. Elsevier, Amsterdam, The Netherlands.

Chapin, F. S., III, P. C. Miller, W. D. Billings, and P. I. Coyne. 1980. Carbon and nutrient budgets and their control in coastal tundra. Pages 458-482 in J. Brown, P. C. Miller, L. L. Tieszen, and F. L. Bunnell, editors. An Arctic ecosystem: the coastal tundra at Barrow, Alaska. Dowden, Hutchinson and Ross, Stroudsburg, Pennsylvania, USA.

Clark, J. S. 1988. Effects of climate change on fire regimes in northwestern Minnesota. Nature 334:233-235.

Clymo, R. S. 1984 . The limits to peat bog growth. Philosophical Transactions of the Royal Society of London B, 303:605-654.

. 1987. The ecology of peatlands. Science Progress, Oxford 71:593-614.

Crill, P. M., K. B. Bartlett, R. C. Harriss, E. Gorham, E. S. Verry, D. I. Sebacher, L. Mazdar, and W. Sanner. 1988. Methane flux from Minnesota peatlands. Global Biogeochemical Cycles 2:317-384

Drury, W. H., Jr. 1956. Bog flats and physiographic processes in the Upper Kuskokwim River region, Alaska. Contributions of the Gray Herbarium, Harvard University, Number 178.

Farrish, K. W., and D. F. Grigal. 1988. Decomposition in an ombrotrophic bog and a minerotrophic fen. Soil Science 145:353-358.

Franklin, J. F., F. J. Swanson, M. E. Harmon, D. A. Perry, T. A. Spies, V. H. Dale, A. McKee, W. K. Ferrell, S. V. Gregory, J. D. Lattin, T. D. Schowalter, D. Larsen, and J. E. Means. 1990. Effects of global climatic change on forests in northwestern North America. In R. L. Peters, editor. Effects of greenhouse warming on biodiversity. Yale University Press, New Haven, Connecticut, USA, in press.

Glaser, P. H., G. A. Wheeler, E. Gorham, and H. E. Wright, Jr. 1981. The patterned mires of the Red Lake Peatland: vegetation, water chemistry and landforms. Journal of Ecology 69:575-599.

Glaser, P. H., and J. A. Janssens. 1986. Raised bogs in eastern North America: transitions in landforms and gross stratigraphy. Canadian Journal of Botany 64:395-415.

Gore, A. J. P., editor. 1983. Ecosystems of the world. Mires: swamp, bog, fen and moor. 4A, General studies, and 4B, Regional studies. Elsevier, Amsterdam, The Netherlands.

Gorham, E. 1974. The relationship between standing crop in sedge meadows and summer temperature. Journal of Ecology 62:487-491.

- 1987. The ecology and biogeochemistry of Sphagnum bogs in central and eastern North America. Pages 315 in A. D. Laderman, editor. Atlantic white cedar wetlands. Westview Press, Boulder, Colorado, USA.

- 1988. Canada's peatlands: their importance for the global carbon cycle and possible effects of "greenhouse" climatic warming. Transactions of the Royal Society of Canada V, 3:21-23.

1990. Biotic impoverishment in northern peatlands. Pages 65-98 in G. M. Woodwell, editor. The earth in transition: patterns and processes of biotic impoverishment. Cambridge University Press, New York, New York, USA.

Grigal, D. F., C. G. Buttleman, and L. Kernik. 1985. Biomass and productivity of the woody strata of forested bogs in northern Minnesota. Canadian Journal of Botany 63: 2416-2424.

Grotch, S. L. 1988. Regional intercomparison of general circulation model predictions and historical climate data. United States Department of Energy (DOE/NBB-0084 TR 041), Washington, D.C., USA.

Harris, S. A., H. M. French, J. A. Heginbottom, G. H. John- ston, B. Ladanyi, D. C. Sego, and R. O. van Everdingen. 1988. Glossary of permafrost and related ground-ice terms. Technical Memorandum, National Research Council of Canada, Number 142.

Harriss, R. C., E. Gorham, D. I. Sebacher, K. B. Bartlett, and P. A. Flebbe. 1985. Methane flux from northern peatlands. Nature 351:652-653.

Harriss, R. C., D. I. Sebacher, and F. P. Day, Jr. 1982. Methane flux in the Great Dismal Swamp. Nature 297:673674.

Heinselman, M. L. 1975. Boreal peatlands in relation to environment. Pages 93-103 in A. D. Hasler, editor. Coupling of land and water systems. Springer-Verlag, New York, New York, USA.

Hofstetter, R. H. 1969. Floristic and ecological studies of Minnesota wetlands. Dissertation. University of Minnesota, Minneapolis, Minnesota, USA.

Houghton, R. A., and G. M. Woodwell. 1989. Global climatic change. Scientific American 260:36-44.

Ivanov, K. E. 1981. Water movement in mirelands. Translated from the Russian by A. Thomson and H. A. P. Ingram. Academic Press, London, England.

Janssens, J. A., B. C. S. Hansen, P. H. Glaser, and C. W. Barnosky. 1990. Development of a raised-bog complex in Northern Minnesota. In H. E. Wright, Jr., B. Coffin, and N. Aaseng, editors. Patterned peatlands of Northern Minnesota. University of Minnesota Press, Minneapolis, Minnesota, USA, in press.

Kivinen, E. 1980. New statistics on the utilization of peatlands in different countries. Pages 48-51 in Proceedings of the Sixth International Peat Congress, Duluth, Minnesota, USA. International Peat Society, Helsinki, Finland.

Kivinen, E., and P. Pakarinen. 1981. Geographical distribution of peat resources and major peatland complex types in the world. Annales Academiae Scientarum Fennicae, Series A, Number 132.

Kulczynski, S. 1949. Peat Bogs of Polesie. Memoires de l'Académie Polonaise des Sciences et des Lettres B, Number 15.

Lachenbruch, A. H., and B. V. Marshall. 1986. Changing climate: geothermal evidence from permafrost in the Alaskan Arctic. Science 234:689-696.

Lappaleinen, E. 1980. The useful fuel peat resources in Finland. Pages 59-63 in Proceedings of the Sixth International Peat Congress, Duluth, Minnesota, USA. International Peat Society, Helsinki, Finland.

Lashof, D. A., and D. R. Ahuja. 1990. Relative contributions of greenhouse gas emissions to global warming. Nature 344:529-531.

Luken, J. O., and W. D. Billings. 1983. Changes in bryophyte production associated with a thermokarst erosion cycle in a subarctic bog. Lindbergia 9:163-168.

Malmström, C. 1923. Degerö Stormyr. Statens Skogsförsöksanstalt (Stockholm) 20:1-207.

—. 1952. Svenska gödlingsförsök för belysande av de näringsekologiska villkoren för skogsväxt på torvmark. Communicationes Instituti Forestalia Fennica 40(17).

Manabe, S., and R. T. Wetherald. 1986. Reduction in summer soil wetness induced by an increase in atmospheric carbon dioxide. Science 232:626-628.

Manabe, S., and R. T. Wetherald. 1987. Large-scale changes of soil wetness induced by an increase in atmospheric carbon dioxide. Journal of Atmospheric Sciences 44:12111235.

Matthews, E., and I. Fung. 1987. Methane emissions from natural wetlands: global distribution, area, and environmental characteristics of sources. Global Biogeochemical Cycles 1:61-86.

McKinzie, W. E. 1982. Quoted on page 10 in R. E. Lucas. Organic soil (Histosols): formation, distribution, physical and chemical properties and management for crop pro- 
duction. Research Report, Farm Science, Michigan State University Agricultural Experiment Station, Number 435.

Miller, P. C., editor. 1981. Carbon balance in northern ecosystems and the potential effect of carbon dioxide induced climatic change. United States Department of Energy (CONF-8003118), Washington, D.C., USA.

Mitchell, J. F. B., and D. A. Warrilow. 1987. Summer dryness in northern mid-latitudes due to increased $\mathrm{CO}_{2}$. Nature 330:238-240.

Mooney, H. S., P. M. Vitousek, and P. A. Matson. 1987. Exchange of materials between terrestrial ecosystems and the atmosphere. Science 238:926-932.

Moore, T. R., and R. Knowles. 1987. Methane and carbon dioxide evolution from subarctic fens. Canadian Journal of Soil Science 67:77-81.

Moore, T. R., and R. Knowles. 1989. The influence of water table levels on methane and carbon dioxide emissions from peatland soils. Canadian Journal of Soil Science 69:33-38.

Neishtadt, M. I. 1977. The world's largest peat basin, its commercial potentialities and protection. International Peat Society Bulletin 8:37-43.

Neustadt, M. I. 1984. Holocene peatland development. Pages 201-206 in A. A. Velichko, editor. Late Quaternary environments of the Soviet Union. University of Minnesota Press, Minneapolis, Minnesota, USA.

Neyshtadt, M. I., L. V. Firsov, L. A. Orlova, and V. A. Panychev. 1974. Some peculiarities of Holocene processes in Western Siberia. Geoforum, Number 17:77-83.

Oechel, W. C. 1989. Nutrient and water flux in a small Arctic watershed: an overview. Holarctic Ecology 12:229-237.

Olson, J. S., J. A. Watts, and L. J. Allison. 1983. Carbon in live vegetation of major world ecosystems. Environmental Sciences Division, Oak Ridge National Laboratory (ORNL-5862), Oak Ridge, Tennessee, USA.

Post, W. M. 1990. Report of a workshop on climate feedbacks and the role of peatlands, tundra, and boreal ecosystems in the global carbon cycle. Oak Ridge National Laboratory (ORNL/TM-11457), Oak Ridge, Tennessee, USA.

Post, W. M., W. R. Emanuel, P. J. Zinke, and A. G. Stangenberger. 1982. Soil carbon pools and world life zones. Nature 298:156-159.

Post, W. M., J. Pastor, P. J. Zinke, and A. G. Stangenberger. 1985. Global patterns of soil nitrogen storage. Nature 317: 613-616.

Riley, J. L. 1982. Hudson Bay Lowland floristic inventory, wetlands catalogue and conservation strategy. Naturaliste Canadien 109:543-555.

. 1987a. The Ontario peatland inventory, 1982-86. Pages 373-382 in C. D. A. Rubec and R. P. Overend, editors. Symposium ' 87 Wetlands/Peatlands. Conference Coordinator, Edmonton, Alberta, Canada.

- 1987b. Peat and Peatland Resources of Northeastern Ontario. Ontario Geological Survey, Open-File Report, Number 5631.

. 1988. Southern Ontario bogs and fens off the Canadian Shield. Pages 355-367 in M. J. Bardecki and N. Patterson, editors. Wetlands: inertia or momentum. Federation of Ontario Naturalists, Don Mills, Ontario, Canada.

Riley, J. L., and L. Michaud. 1987. Peat and peatland resources of Northwestern Ontario. Ontario Geological Survey, Open File Report, Number 5632.

Robinson, D. 1987. Investigations into the Aukhorn peat mounds, Keiss, Caithness: pollen, plant microfossil, and charcoal analysis. New Phytologist 106:185-200.

Sabo, E. D. 1980. Wetland reserves of the USSR and plans for their reclamation. (Translated from the Russian by Language Services, Knoxville, Tennessee, USA, ORNL/TR89/32.) Pages 16-24 in N. I. Pyavchenko, editor. The importance of bogs in the biosphere. Nauka Press, Moscow, USSR.

Schell, D. M. 1983. Carbon-13 and carbon-14 abundances in Alaskan aquatic organisms: delayed production from peat in Arctic food webs. Science 219:1068-1071.

Sebacher, D. I., R. C. Harriss, K. B. Bartlett, S. M. Sebacher, and S. S. Grice. 1986. Atmospheric methane sources: Alaskan tundra bogs, an alpine fen, and a subarctic boreal marsh. Tellus 38B:1-10.

Siegel, D. I. 1983. Ground water and evolution of patterned mires, Glacial Lake Agassiz peatlands, northern Minnesota. Journal of Ecology 71:913-922.

Silvola, U. 1986. Carbon dioxide dynamics in mires reclaimed for forestry in eastern Finland. Annales Botanici Fennici 23:59-67.

Sjörs, H. 1961. Forest and peatland at Hawley Lake, northern Ontario. Bulletin of the National Museum of Canada 171:1-31.

1763. Bogs and fens of Attawapiskat River, Northern Ontario. Bulletin of the National Museum of Canada 186:45-133.

1980. Peat on earth: multiple use or conservation? Ambio 9:303-308.

- 1982. The zonation of northern peatlands and their importance for the carbon balance of the atmosphere. Pages 11-14 in B. Gopal, R. E. Turner, R. G. Wetzel, and D. F. Whigham, editors. Wetlands: ecology and management. National Institute of Ecology, and International Scientific Publications, Jaipur, India.

Stroud, D. A., T. M. Reed, M. W. Pienkowski, and R. A. Lindsay. 1987. Birds, bogs and forestry: the peatlands of Caithness and Sutherland. Nature Conservancy Council, Peterborough, England.

Tamm, C. O. 1951. Chemical composition of birch leaves from drained mire, both fertilized with wood ash and unfertilized. Svensk Botanisk Tidskrift 45:309-319.

. 1965. Some experiences from forest fertilization trials in Sweden. Silva Fennica, Number 117.

Tarnocai, C. 1984. Peat resources of Canada. Land Resource Research Institute, Research Branch, Agriculture Canada, Ottawa, Ontario, Canada.

Tarnocai, C., and S. C. Zoltai. 1988. Wetlands of arctic Canada. Pages 27-53 in C. D. A. Rubec, editor. Wetlands of Canada. Polyscience, Montreal, Canada.

Tilton, D. L. 1975. The growth and nutrition of tamarack (Larix laricina). Dissertation. University of Minnesota, Minneapolis, Minnesota, USA.

Tolonen, K. 1979. Peat as a renewable resource: long-term accumulation rates in North European mires. Pages 282296 in Proceedings of the International Symposium on Classification of Peat and Peatlands, Hyytiala, Finland. International Peat Society, Helsinki, Finland.

Verry, E. S. 1984. Microtopography and water table fluctuation in a Sphagnum mire. Pages 11-31 in Proceedings of the Seventh International Peat Congress, Dublin, Eire. Volume 2. International Peat Society, Helsinki, Finland.

Wahlen, M., N. Tanaka, R. Henry, B. Deck, J. Zeglen, J. W. Vogel, J. Southon, A. Shemesh, R. Fairbanks, and W. Broecker. 1989. Carbon-14 in methane sources and in atmospheric methane: the contribution from fossil carbon. Science 245:286-290.

Walter, H. 1977. The oligotrophic peatlands of Western Siberia - the largest peino-helobiome in the world. Vegetatio 34:167-178.

Whalen, S. C., and W. S. Reeburgh. 1988. A methane flux time series for tundra environments. Global Biogeochemical Cycles 2:399-409.

Whalen, S. C., and W. S. Reeburgh. 1990. Consumption of atmospheric methane by tundra soils. Nature 346:160-162.

Wheeler, G. A., P. H. Glaser, E. Gorham, C. M. Wetmore, F. D. Bowers, and J. A. Janssens. 1983. Contributions to the flora of the Red Lake Peatland, northern Minnesota, with special attention to Carex. American Midland Naturalist 110:62-96. 
Woo, M.-K., and R. Heron. 1987. Effects of forests on wetland runoff during spring. Pages 297-307 in Forest hydrology and forest management. International Association of Hydrological Sciences, Publication Number 167.

Zoltai, S. C. 1988. Wetland environments and classification. Pages 1-26 in C.D.A. Rubec, editor. Wetlands of Canada. Polyscience, Montreal, Quebec, Canada.

Zoltai, S. C., and C. Tarnocai. 1975. Perennially frozen peatlands in the western Arctic and Subarctic of Canada Canadian Journal of Earth Science 12:28-43.

Zoltai, S. C., and F. C. Pollett. 1983. Wetlands in Canada.
Pages 245-268 in A.J.P. Gore, editor. Ecosystems of the World, 4B. Mires: swamp, bog, fen and moor, Regional studies. Elsevier, Amsterdam, The Netherlands.

Zoltai, S. C., and D. H. Vitt. 1990. Holocene climatic change and the distribution of peatlands in western interior Canada. Quaternary Research 33:231-240.

Zurek, S. 1976. The problem of growth of the Eurasia Peatlands in the Holocene. Pages 99-122 in Proceedings of the Fifth International Peat Congress, Poznan, Poland. Volume 2. International Peat Society, Helsinki, Finland. 